Jurnal Neutrino Vol. 3, No. 2, April 2011

\title{
PEMETAAN AIR TANAH MENGGUNAKAN METODE RESISTIVITAS WENNER SOUNDING (Studi Kasus Kampus II Universitas Islam Negeri Maulana Malik Ibrahim Malang)
}

\author{
A.M.Miftahul Huda*
}

\begin{abstract}
Human is khalifa in this earth, it was presented at Qoran (Al-Fathir: 39). Then the earth is authority and responsibility of human to saving and managing. Include of that is aquifer. Aquifer is the water that is available in the throat of geology which permeable. The mapping of aquifer potency is important because it used for developing the collage II Islamic State University Maulana Malik Ibrahim of Malang at Junrejo, Batu. Good water is predicted consume at high level in future. This investigation purposefull to know the place of the potentiality of aquifer in the location of investigation verticality. The method used in this research is Resistivity Geoelectric is an used to investigate the current surface based on stone resistivity. In this case, is used wenner sounding configuration. potentiality of aquifer in the location of investigation verticality. At the every measuring using resistivity meter OYO Mc 2119. The result of the survey show if variety of depth and thick layers of aquifer; whit the best potentiality of aquifer at sounding point $2 \mathrm{C} \mathrm{C}\left(7^{\circ} 55^{\prime} 11,9^{\prime \prime} \mathrm{LS}\right.$ dan $112^{\circ} 32^{\prime} 36,1^{\prime \prime}$ BT) in second line. Potency source of aquifer at hight more than 93,8 meter from surface. Then in first line, potency of aquifer is predicted bad. Cross-correlaton of sounding points showed that formation of geology is sands, sandlimestone, clay, and breccia.
\end{abstract}

Kata Kunci: Qoran, Aquifer, Resistivity method of wenner sounding, Potency of Aquifer.

\section{PENDAHULUAN}

Air Tanah (akuifer) menurut Soekamto (1995), merupakan air yang bertempat di rongga-rongga dalam lapisan geologi (tanah) yang bersifat permeabel (tembus air). Topografi daerah penelitian Tlekung, Junrejo, Batu yang menjadi lokasi kampus II Universitas Islam Negeri Maulana Malik Ibrahim Malang merupakan daerah perbukitan dan berada pada ketinggian rata-rata $876 \mathrm{~m}$ di atas permukaan laut. Pada garis bujur $112^{\circ} 32,549^{\prime} \mathrm{BT}$, dan pada garis lintang $07^{\circ} 55,217^{\prime}$ LS (Wikipedia, 2010).

Masyarakat di sekitar wilayah penelitian umumnya dalam memenuhi kebutuhan air bersih, mereka membuat sumur untuk mengambil air di bawah permukaan bumi. Sumur tersebut dibuat secara tradisional, yaitu membuat lubang hingga menjangkau titik resapan air dengan menggunakan cangkul atau alat bor tanah. Air yang diperoleh

*) Jurusan Fisika Fakultas Sains dan Teknologi UIN Maulana Malik Ibrahim Malang 
dalam sumur galian tersebut adalah air tanah dangkal yang letaknya di atas lapisan kedap air (akuiklud), tidak sampai menembus lapisan akuifer (lapisan tanah yang terbentuk dari material permeabel, terdiri dari pecahan batu, kerikil, dan pasir yang mampu menampung air dalam jumlah besar) yang berada di bawah lapisan akuiklud.

Melihat kondisi yang demikian, maka dalam pengembangan kampus II Universitas Islam Negeri Maulana Malik Ibrahim Malang perlu sekali dilakukan pendekatan keberadaan air di lokasi tersebut. Dengan adanya studi keberadaan air tanah diharapkan mampu membantu pihak pengembang untuk mendapatkan posisi yang tepat dalam eksploitasi air, sehingga pemenuhan kebutuhan air bersih di masa akan datang dapat terpenuhi untuk seluruh aktifitas warga kampus.

Proses penentuan keberadaan air tanah tersebut tentunya membutuhkan metode penentuan yang telah teruji. Salah satu metode ilmiah yang sering digunakan dalam pendeteksian air tanah tersebut adalah dengan mengaplikasikan metode geolistrik resistivitas, yang merupakan salah satu dari metode geofisika.

Megawati (2010) telah mencoba menentukan persebaran air tanah di lokasi kampus II Universitas Islam Negeri Maulana Malik Ibrahim Malang dengan menggunakan metode geolistrik resistivitas konfigurasi schlumberger secara mapping. Dari penelitian tersebut didapatkan kesimpulan bahwa persebaran air tanah dilokasi tersebut dapat diketahui, namun masih terdapat keterbatasan dari penelitian ini, yaitu terbatas hanya untuk mengetahui keberadaan air secara lateral saja, kedalaman dan ketebalan lapisan pembawa air atau keberadaan air secara vertikal yang dapat dijangkau sangat terbatas. Karena itu untuk menjangkau target yang lebih dalam perlu dicoba dengan menggunakan metode lain yang mampu melengkapi metode tersebut. Untuk tujuan ini maka metode yang akan digunakan adalah metode geolistrik resistivitas konfigurasi wenner sounding, penggunaan konfigurasi ini mampu menduga keberadaan air tanah di dalam bumi secara vertikal melalui nilai resistivitas dari batuan.

Prinsip pengukuran metode geolistrik dilakukan dengan cara menginjeksikan arus listrik ke dalam bumi dan mengukur nilai beda potensial yang dihasilkan. Proses injeksi arus dan perekaman beda potensial yaitu dengan menggunakan dua elektroda arus yang posisinya di sisi luar, dan dua buah elektroda potensial yang berada di sisi dalam. Elektroda-elektroda tersebut ditancapkan ke dalam tanah dengan jarak antar elektroda yang saling berdekatan adalah sama. Untuk menjangkau target yang lebih dalam, maka jarak antar elektrodanya dapat diperlebar hingga mencapai panjang bentangan maksimal yang diinginkan.

Keunggulan dari metode ini dari konfigurasi lain seperti schlumberger dan poledipole adalah bahwa metode ini tidak memerlukan tingkat kesensitifan alat pengukur beda potensial atau voltmeter yang tinggi (Milsom, 2003).

Melalui penelitian ini diharapkan dapat merekomendasikan titik keberadaan air tanah dan kedalaman target dari permukaan. Sehingga para pengembang lokasi tersebut 
dapat memperkirakan titik bor yang tepat yang dapat menjangkau kedalaman target yang dimaksud.

\section{KAJIAN TEORI}

Lebih dari $70 \%$ permukaan bumi diliputi oleh samudera yang merupakan reservoir utama air cair di bumi. Air ditemukan diudara dalam bentuk awan dan hujan, dipermukaan bumi air ada di danau dan sungai, dan proses dalam permukaan bumi sebagai air bawah tanah. Air dapat mengubah bentuk tanah melalui proses erosi dan transpor tanah, air meninggalkan atmosfer melalui kondensasi dan kembali ke atmosfer melalui penguapan. Transformasi air melalui semua fasanya disebut siklus air (daur hidrologi), sebagaimana diilustrasikan di dalam gambar berikut.

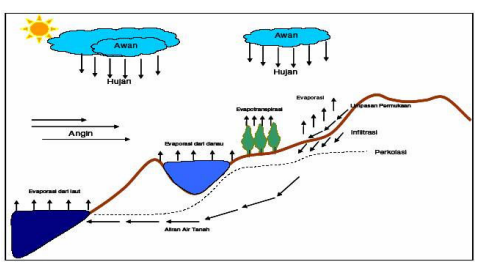

Gambar 1. Sikus air (Soemarto,1987)

Tjasyono (2003) mengatakan bahwa semua air tawar bumi berasal dari air hujan. Sebagian dari air hujan merembes ke dalam tanah sebagai cadangan air tanah dan arus bawah tanah. Sisanya akan kembali ke atmosfer melalui penguapan. Akibat adanya siklus air tersebut, menurut Soemarto (1987) air terbagi atas dua bagian yaitu, air permukaan dan air bawah permukaan (air tanah). permukaan adalah air yang terdapat di sungai, danau, atau rawa air tawar.

Sosrodarsono (2003) mendefinisikan bahwa air tanah adalah air yang bergerak dalam tanah (batuan) yang terdapat di dalam ruang-ruang antara pori-pori batuan retakan-retakan batuan. Air tanah sering disebut sebagai akuifer.

Metode geolistrik resistivitas bekerja karena pengukuran beda potensial pada titiktitik di permukaan bumi yang diproduksi dengan langsung mengalirkan arus ke bawah permukaan. Hal ini bermanfaat untuk menentukan distribusi resistivitas di bawah permukaan dan kemudian digunakan untuk interpretasi material-material yang ada di dalam bumi.

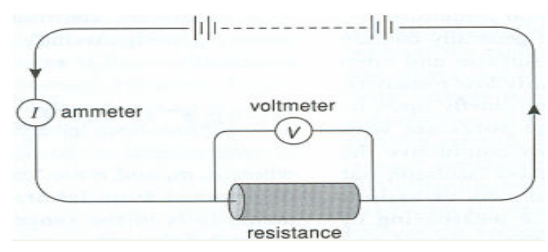

Gambar 2. Rangkaian listrik sederhana (Burger, 1992). 
Hambatan dari resistor sebagaimana yang diilustrasikan pada gambar di atas bergantung pada panjang kolom pipa dan juga material dasar yang menyusunnya, yang kita namakan resistivitas dan dinotasikan dalam $\rho$, sehingga kita dapat menyebutkan bahwa

$$
\rho=R \frac{A}{L}
$$

Satuan dari resistivitas adalah hambatan dikalikan panjang yang dinotasikan dalam ohm meter. Resistivitas merpakan kebalikan dari konduktivitas, begitu juga sebaliknya (Burger, 1992)

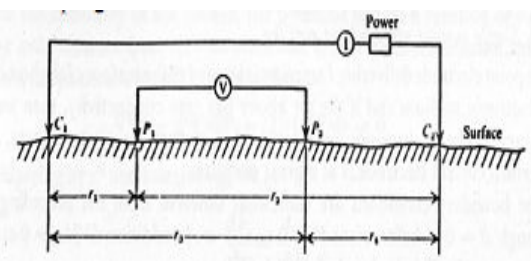

Gambar 3. Dua elektroda arus dan dua elektroda potensial pada permukaan tanah homogen isotropik pada resisitivitas $\rho$ (Telford,1990).

Ketika arus diinjeksikan pada permukaan tanah melalui dua elektroda arus $\mathrm{C} 1$ dan C2, maka beda potensial yang terjadi dari gambar 3, pada elektroda P1 dan P2 adalah:

$$
\Delta V=\frac{I \rho}{2 \pi}\left\{\left(\frac{1}{r_{1}}-\frac{1}{r_{2}}\right)-\left(\frac{1}{r_{z}}-\frac{1}{r_{4}}\right)\right\}
$$

Kemudian, untuk mengukur nilai resistivitas di lapangan digunakan persamaan:

$$
\rho=k\left(\frac{\Delta V}{I}\right)
$$

Namun karena sifat bumi yang pada umumnya berlapis (terutama di dekat permukaan) perandaian bahwa mediumnya adalah homogen tidak terpenuhi. Biasanya resistivitas yang terukur tersebut dikenal sebagai resistivitas semu atau apparent resistivity, yang biasa dituliskan dengan simbol $\rho_{a}$.

Besar resistivitas semu dipengaruhi oleh konfigurasi elektroda yang digunakan, hal ini disebabkan karena setiap konfigurasi elektroda memiliki faktor $k$ yang berbeda berdasar susunan dari elektrodanya. Konfigurasi wenner mempunyai ciri jarak antar elektroda adalah sama, sehingga memberikan faktor geometri $k=2 \pi a_{3}$ yang diperoleh dari

$k=2 \pi\left(\frac{1}{A M}-\frac{1}{M D}-\frac{1}{A N}+\frac{1}{N D}\right)$

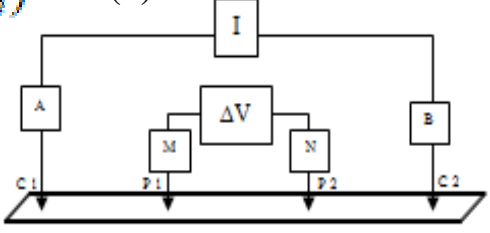

Gambar 4. Konfigurasi wenner (Burger, 1992) 


\section{METODE PENELITIAN}

\section{Bentuk Penelitian}

Penelitian ini bersifat pendugaan potensi air tanah pada studi kasus Kampus II Universitas Islam Negeri Maulana Malik Ibrahim Malang. Meliputi pngambilan data resistivitas, pengolahan data resistivitas, serta interpretasi data resistivitas.

\section{Alat Dan Bahan}

Peralatan penunjang dalam penelitian ini meliputi resistivitymeter $O Y O \mathrm{Mc}$ Ohm 2119, kabel 4 gulung, GPS (Global Positioning System), peta geologi dan hidrogeologi daerah penelitian, meteran, alat tulis dan clipboard, palu, seperangkat laptop dengan $O S$ Microsoft Windows XP 3.

\section{Akuisisi Data}

Pengukuran metode geolistrik konfigurasi wenner sounding, dilakukan dengan menginjeksikan arus melalui dua elektroda arus dan mengukur beda potensial yang dihasilkan dari dua buah elektroda potensial. Perlu diperhatikan dalam perpindahan dan pemasangan elektroda harus sesuai dengan konfigurasi yang digunakan dan dibuat sedemikian rupa agar dapat mempermudah dalam akuisisi data. Dimana penempatan elektroda dan kedalaman elektroda (arus dan potensial) harus benar (lebih kurang 15 $\mathrm{cm}$ ) tertancap di dalam bumi supaya di dapatkan data yang akurat. Selain itu kabel arus dan kabel potensial harus terpasang dengan benar. Data yang terukur adalah kuat arus, beda potensial, dan jarak spasi antar elektroda. Sedangkan data topografi yang didapatkan dari GPS berupa posisi lintang selatan, bujur timur, dan ketinggian pada tiap titik datum.

\section{Processing Data}

Data yang didapatkan dari pengukuran kemudian diolah dengan software IP2win, dengan memasukkan besar nilai arus (I) dan nilai beda potensial $(\Delta \mathrm{V})$ serta jarak spasi elektroda (a) ke dalam software IP2win dan hasilnya berupa tampilan grafik dan nilai resistivitas batuan $\left(\rho_{\mathrm{a}}\right)$ lapisan di bawah permukaan tanah secara vertikal.

Pertama yang harus dilakukan adalah menghitung faktor geometri k untuk konfigurasi wenner dengan persamaan $k=2 \pi a$ kemudian menghitung nilai resistivitas batuan, dimana nilai resistivitas yang didapatkan ini merupakan nilai resistivitas semu atau apparent resistivity. Karena batuan yang berada di bawah permukaan bumi sebenarnya terdiri dari banyak lapisan dengan nilai resistivitas yang berbeda, sehingga bukan resisstivitas sebenarnya yang didapatkan. Untuk mengetahui nilai resisitivitas yang sebenarnya dari masing-masing lapisan. Maka proses yang ditempuh adalah 
dengan melakukan proses inversi hingga didapatkan kesalahan (error) paling kecil (biasanya kurang dari 10\%).

Hasil pengolahan data dengan software IP2win adalah dalam bentuk kurva 2 dimensi dan dalam bentuk tabel. Grafik terdiri dari kurva yang berwarna hitam, biru dan merah. Kurva biru merepresentasikan ketebalan dan batas lapisan pada titik sounding, kurva merah merupakan kurva standart atau kurva acuan, dan kurva hitam merupakan kurva data penelitian.

\section{Interpretasi Data}

Interpretasi data dapat dilakukan berdasarkan hasil processing data berupa tampilan grafik dengan nilai resistivitas tiap lapisan yang divalidasi dengan tabel nilai resistivitas batuan yang telah baku. Hasil interpretasi tersebut merupakan gambaran struktur bawah permukaan tanah dan perlapisan jenis batuan serta kandungan airnya yang didukung oleh peta geologi dan peta hidrogeologi daerah penelitian.

\section{HASIL DAN PEMBAHASAN}

Penelitian ini dilakukan di desa Tlekung, tepatnya di area kampus II Universitas Islam Negeri Maulana Malik Ibrahim Malang. Desa Tlekung, Batu berada pada ketinggian rata-rata $876 \mathrm{~m}$ di atas permukaan laut. Pada $112^{\circ} 32^{\prime} 549^{\prime \prime}$ BT, dan pada $07^{\circ} 55^{\prime} 217^{\prime}$ ' LS. Topografi daerah penelitian adalah berbukit di sebelah barat dan selatan, kemudian terdapat lembah di sebelah timur dan utara.

Penelitian ini dilakukan di 2 (dua) lintasan yang berbeda, yaitu : lintasan pertama yang membentang dari selatan ke utara di sepanjang kandang, lokasi tersebut berada pada posisi $7^{\circ} 55^{\prime} 13,7^{\prime \prime}-7^{\circ} 55^{\prime} 14,4^{\prime \prime}$ LS dan pada posisi $112^{\circ} 32^{\prime} 34,4^{\prime \prime}-112^{\circ} 32^{\prime} 32,1^{\prime \prime}$ BT dan lintasan kedua yang membentang dari berat ke timur, dimulai dari gerbang depan hingga ke ladang yang berada pada lintang $7^{\circ} 55^{\prime} 12,3^{\prime \prime}-7^{\circ} 55^{\prime} 10,9^{\prime \prime}$ LS dan bujur $112^{\circ} 32^{\prime} 34,4^{\prime \prime}-112^{\circ} 32^{\prime} 38,9^{\prime \prime} \mathrm{BT}$.

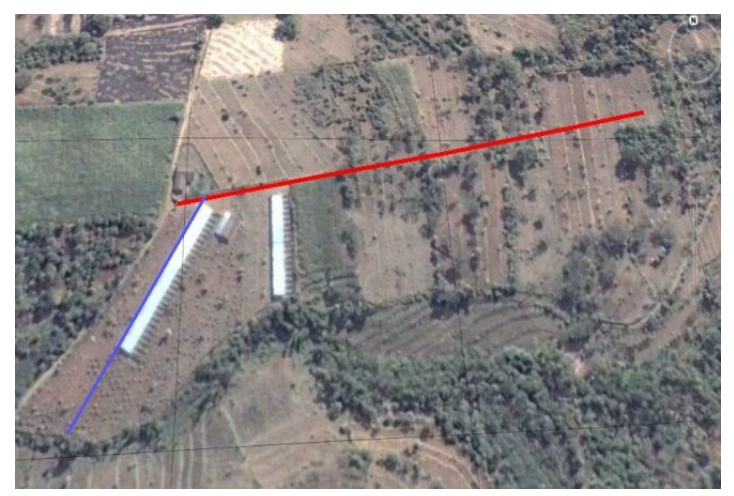

Gambar 5. Lokasi penelitian (garis biru: lintasan pertama; garis merah: lintasan kedua). 


\section{Penentuan Lithologi}

Lokasi daerah penelitian sendiri termasuk dalam Formasi Jombang Qpj dan Formasi Kabuh Qpk. Formasi Jombang Qpj batuannya terdiri atas : breksi, batupasir tufan, batupasir gampingan, konglomerat, lempung dan tuf, juga termasuk dalam Formasi Kabuh Qpk, terdiri atas : batu pasir tufan, batu lempung tufan, batu pasir gampingan, konglomerat, lempung, dan tuf (Megawati, 2010). Menurut Suyono, nilai resistivitas batuan-batuan di atas dapat dikelompokkan sebagai berikut: 1) batu pasir dengan resistivitas 50-500 ohm meter, 2) air tanah dengan resistivitas 30-100 ohm meter, 3) batuan konglomerat dengan resistivitas 100-500 ohm meter, 4) kelompok andesit dengan resistivitas 100-2000 ohm meter, 5) kelompok granit dengan resisitivitas sebesar 1.000-10.000 ohm meter, 6) tufa dengan resistivitas sebesar 20-200 ohm meter (Suyono, 1978). Sedangkan untuk batuan gamping menurut Loke (2006) memiliki nilai resistivitas sebesar 50-400 ohm meter, dan lempung menurut Roy E. Hunt (1984) mempunyai nilai resistivitas sebesar 3-15 ohm meter. Setelah dilakukan interpretasi data, pada titik-titik datum di kedua lintasan penelitian didapatkan hasil sebagai berikut:

\section{Lintasan pertama}

\section{$>$ Titik $1 \mathrm{~A}$}

Titik datum 1 A terletak pada koordinat $7^{\circ} 55^{\prime} 13,7^{\prime \prime}$ LS dan $112^{\circ} 32^{\prime} 33^{\prime \prime}$ BT.

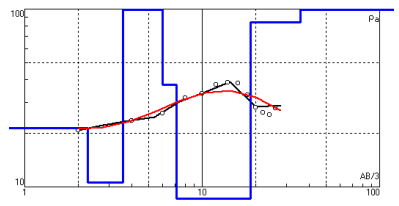

Gambar 6. Pencocokan kurva dan inversi model pelapisan bumi titik datum 1 A.

Gambar 6 menunjukkan pelapisan yang terjadi pada titik datum. Berdasarkan pencocokan dengan geologi penelitian dan tabel resistivitas, maka lapisan penyusun titik datum tersebut dapat diinterpretasikan sebagaimana pada tabel 1.

Tabel 1. Interpretasi lithologi titik datum 1 A

\begin{tabular}{|l|l|l|l|l|}
\hline Lapisan & $\begin{array}{c}\text { Kedalaman } \\
(\mathrm{m})\end{array}$ & \multicolumn{1}{|c|}{$\begin{array}{c}\text { Ketebalan } \\
(\mathrm{m})\end{array}$} & $\begin{array}{c}\text { Resistivitas } \\
(\Omega \mathrm{m})\end{array}$ & \multicolumn{1}{|c|}{ Lithologi } \\
\hline 1 & 2,26 & 2,26 & 21,5 & Pasir lempungan \\
\hline 2 & 3,59 & 1,33 & 10,6 & Lempung \\
\hline 3 & 5,98 & 2,39 & 237 & Batu konglomerat \\
\hline 4 & 7,2 & 1,22 & 37,5 & Pasir tufaan \\
\hline 5 & 18,7 & 11,5 & 4,03 & Lempung \\
\hline 6 & 35,7 & 17 & 84,3 & Pasir tufaan \\
\hline 7 & - & - & 182 & Batu pasir tufaan \\
\hline
\end{tabular}


Titik 1 B

Titik datum $1 \mathrm{~B}$ terletak pada koordinat $7^{\circ} 55^{\prime} 13,7^{\prime \prime} \mathrm{LS}$ dan $112^{\circ} 32^{\prime} 32,5^{\prime \prime} \mathrm{BT}$.

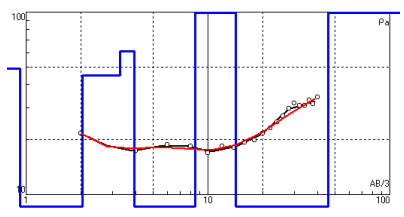

Gambar 7. Pencocokan kurva dan inversi model pelapisan bumi titik datum $1 \mathrm{~B}$

Gambar 7 menunjukkan pelapisan yang terjadi pada titik datum. Berdasarkan pencocokan dengan geologi penelitian dan tabel resistivitas, maka lapisan penyusun titik datum tersebut dapat diinterpretasikan sebagaimana tabel 2.

Tabel 2. Interpretasi lithologi titik datum $1 \mathrm{~B}$

\begin{tabular}{|l|l|l|l|l|}
\hline Lapisan & $\begin{array}{c}\text { Kedalaman } \\
(\mathrm{m})\end{array}$ & \multicolumn{1}{|c|}{$\begin{array}{c}\text { Ketebalan } \\
(\mathrm{m})\end{array}$} & $\begin{array}{c}\text { Resistivitas } \\
(\Omega \mathrm{m})\end{array}$ & \multicolumn{1}{|c|}{ Lithologi } \\
\hline 1 & 0,93 & 0,93 & 48,9 & Pasir tufaan \\
\hline 2 & 2,04 & 1,11 & 7,76 & Lempung \\
\hline 3 & 3,3 & 1,26 & 45,1 & Pasir tufaan \\
\hline 4 & 3,94 & 0,636 & 61,1 & Pasir tufaan \\
\hline 5 & 8,53 & 4,59 & 4,86 & Lempung \\
\hline 6 & 14,3 & 5,75 & 771 & Batu pasir gampingan \\
\hline 7 & 45,7 & 31,4 & 3,18 & Lempung \\
\hline 8 & 57,1 & 11,4 & 1643 & Breksi \\
\hline 9 & - & - & 367 & Batu konglomerat \\
\hline
\end{tabular}

Titik $1 \mathrm{C}$

Titik datum $1 \mathrm{C}$ terletak pada koordinat $7^{\circ} 55^{\prime} 14,4^{\prime \prime} \mathrm{LS}$ dan $112^{\circ} 32^{\prime} 32,1^{\prime \prime} \mathrm{BT}$.

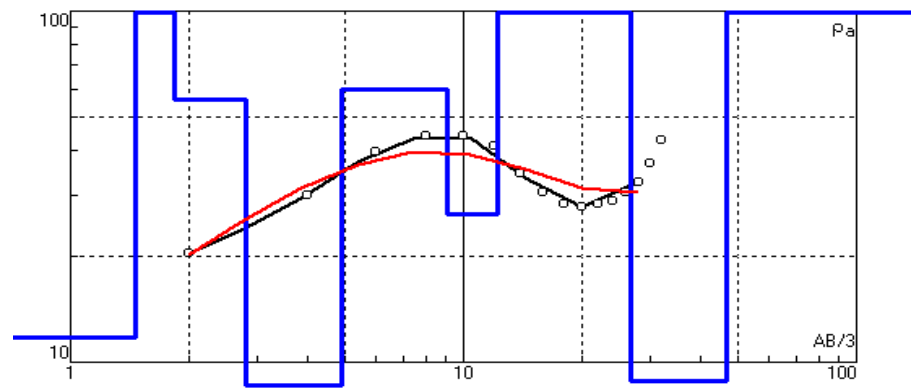

Gambar 8. Pencocokan kurva dan inversi model pelapisan bumi titik datum $1 \mathrm{C}$

Gambar 8 menunjukkan pelapisan yang terjadi pada titik datum. Berdasarkan pencocokan dengan geologi penelitian dan tabel resistivitas, maka lapisan penyusun titik datum tersebut dapat diinterpretasikan sebagaimana tabel 3. 
Tabel 3. Interpretasi lithologi titik datum $1 \mathrm{C}$

\begin{tabular}{|l|l|l|l|l|}
\hline Lapisan & $\begin{array}{c}\text { Kedalaman } \\
(m)\end{array}$ & Ketebalan $(m)$ & $\begin{array}{c}\text { Resistivitas }(\Omega \\
m)\end{array}$ & \multicolumn{1}{|c|}{ Lithologi } \\
\hline 1 & 1,47 & 1,47 & 11,7 & Pasir lempungan \\
\hline 2 & 1,85 & 0,375 & 1039 & Breksi \\
\hline 3 & 2,8 & 0,956 & 55,9 & Pasir tufaan \\
\hline 4 & 4,91 & 2,11 & 1,94 & Lempung \\
\hline 5 & 9,12 & 4,21 & 59,6 & Pasir tufaan \\
\hline 6 & 12,2 & 3,1 & 26,5 & Pasir tufaan \\
\hline 7 & 26,5 & 14,3 & 737 & Batu pasir gampingan \\
\hline 8 & 46,6 & 20,1 & 8,83 & Lempung \\
\hline 9 & - & - & 1364 & Breksi \\
\hline
\end{tabular}

\section{Lintasan kedua}

\section{Titik 2 A}

Titik datum 2 A terletak pada koordinat $7^{\circ} 55^{\prime} 12,3^{\prime \prime}$ LS dan $112^{\circ} 32^{\prime} 34,4^{\prime \prime} \mathrm{BT}$.

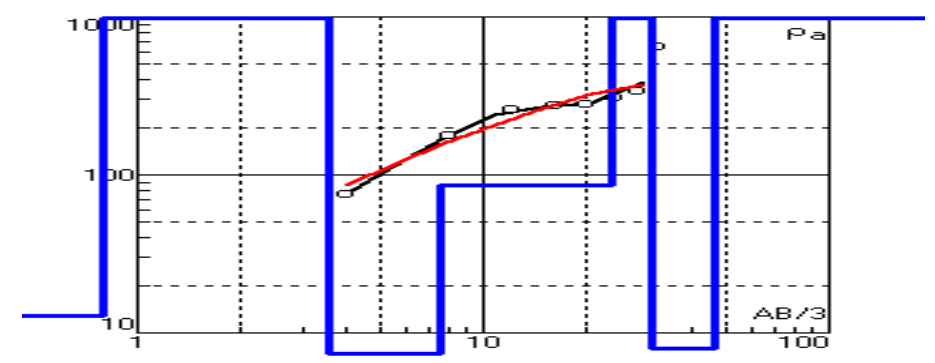

Gambar 9. Pencocokan kurva dan inversi model pelapisan bumi titik datum 2 A

Gambar 9 menunjukkan pelapisan yang terjadi pada titik datum. Berdasarkan pencocokan dengan geologi penelitian dan tabel resistivitas, maka lapisan penyusun titik datum tersebut dapat diinterpretasikan sebagaimana tabel 4.

Tabel 4. Interpretasi lithologi titik datum 2 A

\begin{tabular}{|l|l|l|l|l|}
\hline Lapisan & $\begin{array}{c}\text { Kedalaman } \\
(\mathrm{m})\end{array}$ & \multicolumn{1}{|c|}{$\begin{array}{c}\text { Ketebalan } \\
(\mathrm{m})\end{array}$} & $\begin{array}{c}\text { Resistivitas } \\
(\Omega \mathrm{m})\end{array}$ & \multicolumn{1}{|c|}{ Lithologi } \\
\hline 1 & 0,795 & 0,795 & 12,7 & Pasir lempungan \\
\hline 2 & 1,31 & 0,513 & 2193 & Breksi \\
\hline 3 & 3,6 & 2,29 & 10116 & Breksi \\
\hline 4 & 7,54 & 3,94 & 4,64 & Lempung \\
\hline 5 & 23,5 & 16 & 86 & Pasir tufaan \\
\hline 6 & 30,7 & 7,12 & 1055 & Breksi \\
\hline 7 & 46,5 & 15,8 & 7,79 & Lempung \\
\hline 8 & - & - & 2383 & Breksi \\
\hline
\end{tabular}


Titik 2 B

Titik datum 2 B terletak pada koordinat $7^{\circ} 55^{\prime} 12^{\prime \prime}$ LS dan $112^{\circ} 32^{\prime} 35,1^{\prime \prime}$ BT.

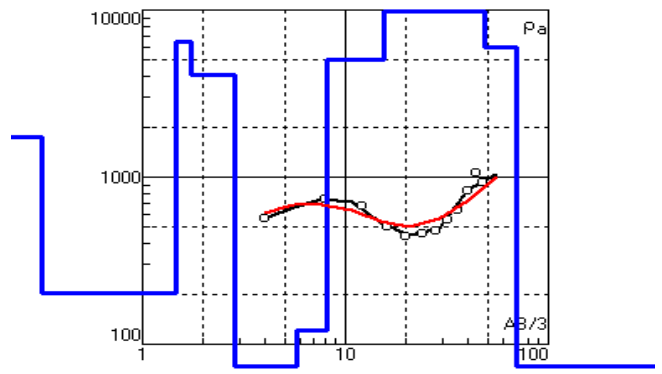

Gambar 10. Pencocokan kurva dan inversi model pelapisan bumi titik datum 2 B

Gambar 10 menunjukkan pelapisan yang terjadi pada titik datum. Berdasarkan pencocokan dengan geologi daerah penelitian dan tabel resistivitas, maka lapisan penyusun titik datum tersebut dapat diinterpretasikan sebagaimana tabel 5 .

Tabel 5. Interpretasi lithologi titik datum 2 B

\begin{tabular}{|l|l|l|l|l|}
\hline Lapisan & Kedalaman $(\mathrm{m})$ & Ketebalan $(\mathrm{m})$ & Resistivitas $(\Omega \mathrm{m})$ & \multicolumn{1}{|c|}{ Lithologi } \\
\hline 1 & 0,317 & 0,317 & 1734 & Breksi \\
\hline 2 & 1,46 & 1,14 & 201 & Batu konglomerat \\
\hline 3 & 1,73 & 0,269 & 6478 & Breksi \\
\hline 4 & 2,85 & 1,12 & 4097 & Breksi \\
\hline 5 & 5,75 & 2,9 & 59,7 & Pasir tufaan \\
\hline 6 & 8,12 & 2,37 & 120 & Batu pasir tufaan \\
\hline 7 & 15,5 & 7,37 & 5026 & Breksi \\
\hline 8 & 48,8 & 33,3 & $1,4 \mathrm{E}+5$ & Breksi \\
\hline 9 & 69,4 & 20,6 & 5970 & Breksi \\
\hline 10 & - & - & 61,8 & Pasir tufaan \\
\hline
\end{tabular}

\section{Titik $2 \mathrm{C}$}

Titik datum $2 \mathrm{C}$ terletak pada koordinat $7^{\circ} 55^{\prime} 11,9^{\prime \prime} \mathrm{LS}$ dan $112^{\circ} 32^{\prime} 36,1^{\prime \prime} \mathrm{BT}$.

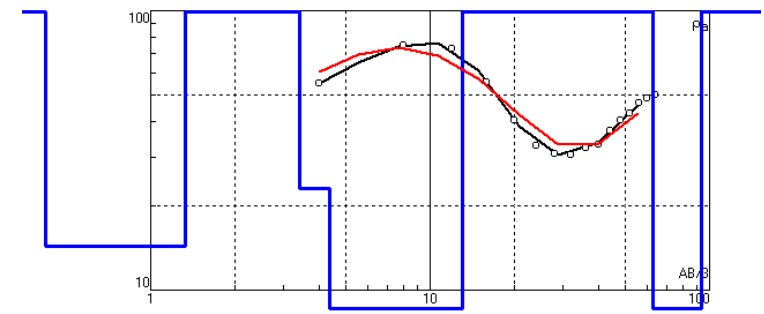

Gambar 11. Pencocokan kurva dan inversi model pelapisan bumi titik datum $2 \mathrm{C}$

Gambar 11 menunjukkan pelapisan yang terjadi pada titik datum. Berdasarkan pencocokan dengan geologi penelitian dan tabel resistivitas, maka lapisan penyusun titik datum tersebut dapat diinterpretasikan sebagaimana tabel 6. 
Tabel 6. Interpretasi lithologi titik datum $2 \mathrm{C}$

\begin{tabular}{|l|l|l|l|l|}
\hline Lapisan & Kedalaman $(\mathrm{m})$ & $\begin{array}{c}\text { Ketebalan } \\
(\mathrm{m})\end{array}$ & $\begin{array}{c}\text { Resistivitas } \\
(\Omega \mathrm{m})\end{array}$ & \multicolumn{1}{|c|}{ Lithologi } \\
\hline 1 & 0,381 & 0,381 & 289 & Batu pasir tufaan \\
\hline 2 & 0,42 & 0,0393 & 317 & Batu konglomerat \\
\hline 3 & 1,33 & 0,907 & 14,3 & Pasir lempungan \\
\hline 4 & 2,56 & 1,23 & 537 & Batu pasir gampingan \\
\hline 5 & 3,42 & 0,859 & 213 & Batu konglomerat \\
\hline 6 & 4,39 & 0,97 & 23,2 & Pasir tufan \\
\hline 7 & 13 & 8,61 & 5,18 & Lempung \\
\hline 8 & 19,5 & 6,51 & 236 & Batu konglomerat \\
\hline 9 & 62,5 & 43 & 11083 & Breksi \\
\hline 10 & 93,6 & 31,1 & 7,84 & Lempung \\
\hline 11 & - & - & 99,1 & Pasir tufaan \\
\hline
\end{tabular}

Titik 2 D

Titik datum 2 D terletak pada koordinat $7^{\circ} 55^{\prime} 11,5^{\prime \prime}$ LS dan $112^{\circ} 32^{\prime} 37,3^{\prime \prime}$ BT.

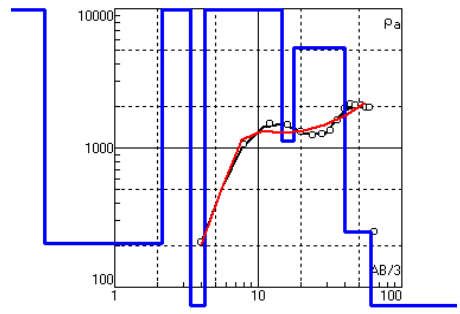

Gambar 11. Pencocokan kurva dan inversi model pelapisan bumi titik datum 2D

Gambar 11 menunjukkan pelapisan yang terjadi pada titik datum. Berdasarkan pencocokan dengan geologi penelitian dan tabel resistivitas, maka lapisan penyusun titik datum tersebut dapat diinterpretasikan sebagaimana tabel 7.

Tabel 7. Interpretasi lithologi titik datum $2 \mathrm{D}$

\begin{tabular}{|l|l|l|l|l|}
\hline Lapisan & Kedalaman $(\mathrm{m})$ & Ketebalan $(\mathrm{m})$ & Resistivitas $(\Omega \mathrm{m})$ & \multicolumn{1}{|c|}{ Lithologi } \\
\hline 1 & 0,326 & 0,326 & $2,4 \mathrm{E}+8$ & Breksi \\
\hline 2 & 2,15 & 1,82 & 208 & Batu konglomerat \\
\hline 3 & 3,38 & 1,23 & 15910 & Breksi \\
\hline 4 & 4,22 & 0,847 & 41,3 & Pasir tufaan \\
\hline 5 & 14,5 & 10,3 & 47048 & Breksi \\
\hline 6 & 17,8 & 3,29 & 1122 & Breksi \\
\hline 7 & 40,4 & 22,6 & 5275 & Breksi \\
\hline 8 & 60,7 & 20,3 & 251 & Batu konglomerat \\
\hline 9 & 93,8 & 33,1 & 69 & Pasir tufaan \\
\hline 10 & - & - & 5,39 & Lempung \\
\hline
\end{tabular}




\section{Penentuan Zona Akuifer}

Setelah mengindikasi lithologi batuan penyusun tiap lapisan, selanjutnya adalah memperkirakan model keberadaan air tanah yang kemungkinan terdapat pada tiap sumur. Teknik yang ditempuh adalah melakukan korelasi (cross-correlation) tiap titik datum, sehingga dapat diduga kontinuitas dari lapisan-lapisan penyusun tersebut, juga dimungkinkan untuk mengetahui aliran air tanah jika didapatkan formasi penyusunnya.

Hasil penampang lintang (cross section) pada masing-masing lintasan adalah sebagai berikut:

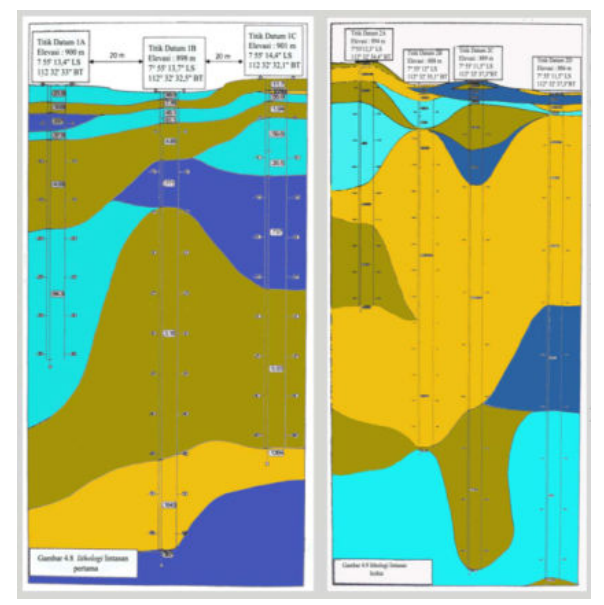

Gambar 12. Penampang lintang, kiri (lintasan pertama); kanan (lintasan kedua).

Keterangan:

warna $\square \quad$ : Lapisan dengan nilai resistivitas $<20 \mathrm{ohm}$ meter

warna $\square \quad$ : Lapisan dengan nilai resistivitas 20-200 ohm meter

warna $\square$ : Lapisan dengan nilai resistivitas 200-1000 ohm meter

warna $\square \quad$ : Lapisan dengan nilai resistivitas > 1000 ohm meter

Dilihat dari kedua model korelasi tersebut, maka dapat disimpulkan bahwa dugaan potensi air tanah hanya berada pada lintasan kedua, sedangkan lintasan pertama tidak mempunyai potensi yang bagus. Posisi yang tepat untuk dilakukan pemboran pada lintasan kedua, yaitu pada titik datum $2 \mathrm{C}$, dengan koordinat antara $7^{\circ} 55^{\prime} 11,5^{\prime \prime} \mathrm{LS}$ dan $112^{\circ} 32^{\prime} 37,3^{\prime \prime}$ BT dengan kedalaman mencapai 90 meter lebih. Pada titik ini dimungkinkan adalah akuifer dalam dan dimungkinkan sangat besar potensi airnya.

\section{KESIMPULAN}

Pengukuran dengan menggunakan metode geolistrik resistivitas konfigurasi wenner sounding mampu memberikan informasi nilai resistivtas batuan pada titik pengukuran (datum), guna menduga formasi batuan pembawa sifat air tanah (akuifer). 
1. Secara hidrogeologis, formasi batuan pembawa sifat air tanah didominasi oleh batuan gunung api. Lapisan akuifer terdiri dari pasir tufaan; lapisan akuitard terdiri dari pasir lempungan, batu pasir gampingan dan batu pasir tufaan; lapisan akuiklud terdiri dari lempung; lapisan akuifuge terdiri dari breksi dan batu konglomerat. Lokasi penelitian termasuk dalam kategori potensi air tanah (akuifer) yang rendah.

2. Interpretasi geologi pada lintasan pertama menunjukkan bahwa pada lintasan pertama lapisannya didominasi oleh lapisan yang tidak memiliki sifat pembawa air tanah, sehingga potensi air tanah menjadi tidak produktif. Sedangkan pada lintasan kedua, interpretasi keadaan geologi tidak dapat dilakukan secara sempurna, dikarenakan formasi penyusunnya tidak mempunyai keselarasan yang baik, namun pada lintasan kedua diduga memiliki potensi air tanah yang cukup baik, melihat penyusun formasinya didominasi oleh pasir tufaan dan juga breksi.

3. Pada lintasan pertama air tanah berada pada titik datum 1 A yang berada pada koordinat 755'13,7" LS dan 112 $32^{\circ} 33^{\prime \prime}$ BT. Kedalaman lapisan air tanah mencapai 18,7 meter di bawah permukaan. Potensi air tanah pada titik ini tergolong baik dengan ketebalan lapisan mencapai 17 meter dan disusun oleh pasir tufaan, dan diduga lapisan air tanah ini tergolong dalam lapisan akuifer dangkal. Sedangkan untuk lintasan kedua, lapisan air tanah yang potensial untuk dilakukan pengeboran berada pada titik datum $2 \mathrm{C}$ dan berada pada koordinat $7^{\circ} 55^{\prime} 11,9^{\prime \prime}$ LS dan $112^{\circ} 32^{\prime} 36,1^{\prime \prime}$ BT. Kedalaman lapisan air tanah mencapai lebih dari 93 meter dengan batuan penyusunnya berupa pasir tufaan dan diduga adalah akuifer dalam.

\section{DAFTAR PUSTAKA}

Burger, Henry Robert.1992. Exploration Geophisics Of The Shallow Subsurface. New Jersey: Prentice Hall.

http://wikipedia.kotabatu.co.id. Diakses pada tanggal 15 Desember 2010 pukul 20:13 WIB.

http://www.batukota.go.id/index.php. Diakses pada 15 Desember 2010 pukul 20:28 WIB.

Irjan, dkk. 2010. Pemetaan Potensi Air Tanah (Aquifer) Berdasarkan Interpretasi Data Resistivitas Wenner sounding UIN MALIKI Malang. Laporan Penelitian tidak dipublikasikan.

Megawati. 2010. Eksplorasi Potensi Air Tanah (Aquifer) Menggunakan Metode Geolistrik Resistivitas 2d Konfigurasi Schlumberger (Studi Kasus Di Lokasi Kampus II UIN MALIKI Malang). Skripsi tidak dipublikasikan.

Milsom, John. 2003. Field Geophysics Third Edition. Chichester: John Wiley \& Sons Ltd. 
Soekamto, Hadi. 1995. Geosfer dan Lingkungan Kehidupan. Malang: Departemen Pendidikan dan Kebudayaan IKIP Malang, Proyek Operasional dan Perawatan Fasilitas IKIP Malang.

Sosrodarsono, Suyono. 1993. Hidrologi Untuk Pengairan PT Pramadya Pramita Edisi Ketiga. Jakarat: Erlangga.

Tjasyono HK, Bayong. 2003. Geosains. Bandung: Penerbit ITB

Telford, WM., 1990. Applied Geophysics Second Edition. Cambridge: Cambridge University Press. 